wiada się, że król Hiszpanii jest królem ludu - ponieważ jego poddani są mu posłuszni; król Francji - królem monet, z uwagi na jego niekończące się nakładanie podatków; a król Anglii - królem diabłów, gdyż jego poddani często dopuszczają się insurekcji przeciwko swoim władcom i obalają ich.

PRZEŁOŻY PIOTR MUSIEWICZ

$\sim$

PAWE $\longleftarrow$ GRELA

Wydział Politologii i Studiów Międzynarodowych UMK

\title{
Gelazjański model sprawowania władzy monarszej w Christianitas. Na marginesie koncepcji Roberta Filmera
}

W kontekście rozważań Roberta Filmera podjętych w Patriarsze warto pamiętać, że teoria monarchii absolutnej nie była jedynym przejawem nurtu myślenia o państwie jako o królestwie. W europejskiej tradycji namysłu nad władzą pojawiają się również inne koncepcje opisujące źródła władzy monarszej oraz rozległości jej potestas, niekoniecznie zbieżne z ideami Anglika. Jedną z takich koncepcji wspomnimy w niniejszym tekście. Postaramy się bowiem przedstawić w zarysie średniowieczną doktrynę dwóch mieczy, którą możemy umiejscowić czasowo w początkach tej epoki. Omówioną tu ideę uznać należy za jeden $\mathrm{z}$ ważniejszych teoretycznych wyrazów myślenia obecnego w ramach nurtu monarchicznego, który porusza kwestie charakteru władzy królewskiej oraz zakresu materialnego zwierzchnictwa królewskiego imperium.

Zanim jednak zrealizujemy nasz główny cel, odniesiemy się pokrótce do myśli Roberta Filmera. Urodzony w Kent w roku 1588 Anglik uważany jest za jednego z głównych teoretyków monarchii absolutnej. Przypisuje się mu autorstwo doktryny boskiego prawa królów, w ramach której to Filmer daje wyraz swojemu przekonaniu o bezwzględnej i nieograniczonej zwierzchności władzy monarchy na ziemi. Tak szeroki zakres monarszego imperium uzasadniał Anglik wywodzeniem się władzy królewskiej bezpośrednio od Boga. 
W swych dociekaniach apologeta absolutyzmu sięga aż do pierwszych rodziców - Adama i Ewy ${ }^{1}$. Władca jawi się w namyśle autora jako ojciec obdarzony władzą niepodlegającą ograniczeniom. Uprawnienie przysługujące królowi należy mu się ze względu na boskie nadanie. $Z$ tego też powodu wola władcy nie napotyka jakichkolwiek ograniczeń w działaniu. Monarcha jest suwerenem we własnym państwie.

Warty przypomnienia jest fakt, że myśl Roberta Filmera stanowi zerwanie ze średniowieczną teorią monarchii. W tym aspekcie zatem zwiastuje nadejście nowoczesności, która odchodzi od koncepcji monarchii ograniczonej, regimentum mixtum, traktowanej jako pluralna wspólnota, samorządnych cechów, stanów, z władzą rozproszoną pośród poddanych i praktycznym brakiem suwerenności jako takiej. Koncepcji, w której monarcha pełnił funkcję czynnika organizującego organizm monarchii i nadającego cel wspólnocie politycznej. Myśl Filmerowska prezentuje monarchię jako scentralizowany ustrój polityczny wykluczający rozproszenie suwerenności oraz traktowanie państwa jako jednego z tworów umieszczonych w szeregu bytów na drodze ku ostatecznemu telosowi. Anglik wpisuje się w szereg takich myślicieli jak Tomasz Hobbes czy Jean Bodin. Kontynuację praktyczną myśl Roberta Filmera znajduję między innymi w koncepcji monarchii absolutnej Ludwika XIV („państwo to ja”) czy w wizji oświeceniowych monarchii absolutnych (Prusy, Rosja, Austria).

Początki średniowiecznego namysłu nad władzą królewską, z którą to propozycją Filmer niejako zrywa, sięgają okresu upadku cesarstwa rzymskiego. To w owym czasie ukształtowała się idea monarchii ograniczonej, odmiennej od Filmerowskiej. Jej autorem był św. Gelazy I. Sformułował on w 496 roku teorię przedstawiającą władzę jako podobną mieczowi, przy czym wskazywał na istnienie dwóch mieczy - egzemplifikacji dwóch władz: „Dwie są, Cesarzu Auguście, naczelne władze, które rządzą światem: uświęcona powaga biskupów i zwierzchność cesarska" ${ }^{2}$. Swą genezę idea ta znajduje w Ewangelii św. Łukasza, a konkretnie w słowach Jezusa Chrystusa wypowiedzianych podczas Ostatniej Wieczerzy: „Kto ma sakiewkę, niech ją weźmie, a także torbę, kto zaś nie ma, niech sprzeda płaszcz i kupi miecz [...] Oni zaś rzekli: Panie oto tutaj dwa miecze. Powiedział im: Wystarczy!" ${ }^{3}$. Słowa te dla Gelazego stają się instrukcją Chrystusa odnośnie do sposobu budowy państwa, które powinno zostać oparte na symbiozie dwóch władz, któ-

Zob. R. Filmer, Patriarcha. O naturalnej władzy królów, w tym numerze s. 4-5.

Św. Gelazy I, Dwunasty list do cesarza Anastazego z roku 494, [w:] Kościót i państwo we wczesnym chrześcijaństwie, red. H. Rahner, przeł. M. Radożycka, J. Radożycki, Warszawa 1986, s. 167. Łk 22:36-38, Biblia Tysiąclecia, Poznań 2003. 
rych współdziałanie powinno rządzić światem ${ }^{4}$. Doktryna tu omawiana była próbą uporządkowania relacji łączących dwa organizmy nieuchronnie występujące obok siebie. Autor próbuje znaleźć formułę, która pozwoliłaby pogodzić ze sobą przenikające się światy: chrześcijańskiej wspólnoty wiernych oraz doczesnej wspólnoty poddanych władzy świeckiej.

Genetycznie doktryna dwóch mieczy czerpie z konfliktu narastającego pomiędzy cesarstwem a Kościołem, który swój początek znajduje w wieku IV po Chrystusie. W owym czasie pojawia się problem roli i kompetencji cezara w odniesieniu do Kościoła wzmocniony faktem, iż chrześcijaństwo staje się religią legalną. Cezar w zgodzie z zasadami rzymskiej polityki religijnej staje się najwyższym kapłanem religii chrześcijańskiej. W konsekwencji następuje sakralizacja władzy cesarza. Przykładem takiego sposobu myślenia może być w tym kontekście dzieło Euzebiusza z Cezarei pt. Życie Konstantyna ${ }^{5}$. Teolog kreśli w nim obraz cezara występującego w roli zwierzchnika Kościoła i jego protektora; naśladowcy Chrystusa - boskiego Logosu. Konstantyn staje się zatem bojownikiem o wiarę. Między cesarzem a Bogiem występuje stosunek pewnego rodzaju równości. Władca tym samym, jako głowa cesarstwa, staje się zwierzchnikiem Kościoła, który tutaj identyfikowany jest z cesarstwem ${ }^{6}$.

Opis Euzebiusza z Cezarei jest wyrazem koncepcji zwierzchnictwa ziemskiego jako monarchii „z łaski Bożej”. Z chwilą, gdy Konstantyn uwalnia religię chrześcijańską od prześladowań, legalizując ją, następuje połączenie cesarza z Bogiem, nieba z rzymską civitas. Idąc dalej, imperium rzymskie znajduje się od tej chwili pod opieką nieba ${ }^{7}$.

Taka wizja władzy staje się oczywistym zagrożeniem dla niezależności Kościoła. Omnipotencja świeckiego imperatora czerpiąca ze wzorów rzymskiego, pogańskiego cezara-imperatora, staje bowiem w sprzeczności z ewangeliczną zasadą rozdziału sfer sacrum i profanum.

Jednym z pierwszych oponentów sprzeciwiających się koncepcji omnipotencji państwa był, jeszcze przed Gelazjuszem, biskup Mediolanu św. Ambroży. Występował on przeciwko zbrodniom cesarza Teodozjusza w Tessalonice, gdy ten doprowadził tam do masowego mordu. Była to

\footnotetext{
T. Dobrzeniecki, Teoria dwóch mieczy w programie sądu ostatecznego, „Rocznik Historii i Sztuki" 1995, t. XXI, s. 21.

Euzebiusz z Cezarei, Życie Konstantyna, przeł. T. Wnętrzak, Kraków 2007.

Zob. T. Wnętrzak, Konstantym Wielki w oczach Euzebiusza z Cezarei i w badaniach wspótczesnych historyków [w:] Euzebiusz z Cezarei, Życie Konstantyna, przeł. T. Wnętrzak, Kraków 2007, s. 84 .

Por. D. E. Madejski, Complexio oppositiorum. Dioklecjańska tetrarchia „z łaski bogów” jako pierwowzór średniowiecznej monarchii „z łaski Bożej”, „Templum Novum” 2004, nr 1, s. 176; por. M. Y. Perrin, Wizja chrześcijańskiego cesarstwa. Teologia polityczna i teologia historii, [w:] Historia chrześcijaństwa, red. A. Corbin, przeł. A. Kocot, Kraków 2009, s. 48.

Zob. Kościót i państwo...., s. 87.
} 
pierwsza próba zastosowania formuły dwóch mieczy, wiek przed jej teoretyczną konkretyzacją ${ }^{9}$. Wymiernym efektem jej użycia był fakt, iż mediolański patriarcha zakazał wstępu cesarzowi do świątyni.

Walka Ambrożego z porywczym cesarzem Teodozjuszem obrazuje kierunek, w którym zmierzał namysł nad relacjami tronu i ołtarza. Doktor Kościoła pragnął zwrócić uwagę na występowanie pewnej precedencji w sprawach wiary oraz moralności. Sfera sacrum i moralności okazuje się dominium zarezerwowanym dla władzy kościelnej. Św. Ambroży, odnosząc się do zajść w Tessalonice, piętna grzechu i hańby z tym związanego, pisał: „Zmażesz je, gdy ukorzysz przed Bogiem duszę swoją. [...] Tłumaczę, proszę, upominam, ostrzegam [...] nie odważę się złożyć w twojej obecności Najświętszej Ofiary, bo mi tego zabrania [...] strach przed Bogiem" ${ }^{\text {"10 }}$. Mediolański pasterz w powyższym passusie, wyjętym z listu do cesarza Teodozjusza, stawia się w roli swego rodzaju moralnego arbitra władzy świeckiej, która owszem, ma kompetencje do zarządzania sprawami wchodzącymi w zakres porządku profanum. Zarazem jednak rola Kościoła jawi się jako bycie instytucją mitygującą władcę i zachęcającą go do poczynań pozostających w zgodzie z nakazami doktryny chrześcijańskiej, ograniczając w ten sposób państwowe imperium. Kościół bowiem strzeże moralnego charakteru poczynań władzy, a w sytuacjach napięcia i bezprawia nakłada kary. W przypadku mediolańskiego biskupa były to zakaz wstępu do świątyni oraz wymóg odpokutowania grzechów ${ }^{11}$.

Dobitniej kwestię rozdziału władz widać na przykładzie cytatu z innego listu biskupa do cesarza Walentyniana, gdzie patriarcha stwierdza: „Podatek należy do Cezara - dlatego mu się go nie odmawia. Kościół należy do Boga i nie może być oddany pod władzę Cezarowi, ponieważ Cezar nie ma żadnej władzy nad świątynią Boga" ${ }^{\text {"12 }}$. Ambroży nie pozostawia wątpliwości co do swojego sposobu rozumienia relacji tronu i ołtarza. Kościół jawi się dla niego w świetle powyższych słów jako instytucja niezależna od sankcji państwowej. Poddana jest jedynie Bogu. Biskup w sposób jasny określa wspólnotę kościelną jako domenę Stwórcy. Cesarz zatem, mimo że jednak stoi ponad prawem, jest podległy Bogu, skrępowany prawem prywatnym, własnością ziemską, szacunkiem poddanych, słowem - ograniczony swoim sumieniem ${ }^{13}$.

T. Molnar, Pałac, Kościót i społeczeństwo cywilne, „Fronda” 2001, nr 25/26, s. 169.

Ambroży z Mediolanu, 51 list do cesarza Teodozjusza z maja 390 r., [w:] Kościót $i$ państwo..., s. $122-123$.

Kara nałożona na Teodozjusza została wyegzekwowana. Cesarz przez osiem miesięcy czynił pokutę - aż do świąt Bożego Narodzenia 390 roku; zob. Kościót i państwo..., s. 87.

Ambroży z Mediolanu, List do cesarza Walentyniana II z marca 386 r., [w:] Kościót i państwo..., s. 120 .

Tamże, s. 80 . 
Monarchia w spekulacjach św. Ambrożego jest ustrojem umiarkowanym, ograniczającym władzę panującego. Egzemplifikacją moderującego charakteru idei mediolańskiego obrońcy wiary jest poniższy cytat, w którym patriarcha konstatuje: „Wszyscy ludzie zamieszkujący obszary podległe prawu rzymskiemu służą Wam, Cesarzom, którzy jesteście panami ziemi. Wy zaś macie służyć Bogu i najświętszej wierze. Nie ma bowiem innej drogi wiodącej do pomyślności państwa jak ta, żeby każdy wielbił w prawdzie jedynego, prawdziwego Boga, który wszystkim rządzi" ${ }^{14}$. Władca nie jest omnipotentnym panem w swoim regno. Określony został mianem sługi. Tylko posługa sprawowana przez cesarza w zgodzie z dyrektywami wiary chrześcijańskiej przybliża do pomyślności całą wspólnotę polityczną. Wola władcy, w kontekście tego cytatu, zostaje silnie ograniczona.

Jakże inna jest to koncepcja władzy od tej zaprezentowanej nam przez Euzebiusza z Cezarei, gdzie - jak pamiętamy - to władca stawał się bezpośrednim naśladowcą Chrystusa - Logosu. Słowa Ambrożego są - w konsekwencji - próbą wprowadzenia w życie ewangelicznej zasady mówiącej o tym, aby oddać cesarzowi, co cesarskie, a Bogu, co boskie.

Te historyczne antytendencje prowadzą nas do doktryny „dwóch mieczy" jako pełnego teoretycznego wyrazu myśli, jaką w swych listach wyrażał mediolański biskup św. Gelazy I. Idąc tropem Ambrożego, interpretował on władzę cesarską jako odrębną od władzy kościelnej, wprowadzając rozgraniczenie pomiędzy dwoma ośrodkami autorytetu. Papież, odnosząc się do problemu separacji zwierzchności, stwierdza w jednym z listów: „Chrystus [...] tak właśnie rozdzielił funkcje obu władz, przydzielając każdej odrębne pole działania i odrębne godności, ponieważ chciał [...] aby cesarze chrześcijańscy potrzebowali kapłanów ze względu na życie wieczne i kapłani stosowali się do rozporządzeń cesarskich" ${ }^{15}$.

Władza zarówno cesarska, jak i papieska pochodzi od Boga. Mimo tego Gelazy buduję pewną hierarchię zwierzchności. Kościół jawi się tutaj jako duchowa część rzeczywistości, państwo jest z kolei ciałem. Skoro tak, zaakcentowana została zależność władcy od instancji kościelnych. Jak konstatował Hugo Rahner: „Gelazy uznaje takie duchowo cielesne podporządkowanie, które stawia sprawy niebieskie ponad ziemskimi"16. Wykonawcę spraw niebieskich widział oczywiście w Kościele.

Spoglądając z instytucjonalnego punktu widzenia, obserwujemy, że doktryna dwóch mieczy wprowadza rozdział pomiędzy dwoma autorytetami, jednocześnie kładąc nacisk na niezależność „pałacu” oraz „świątyni”.

Ambroży z Mediolanu, Epistola 17, 1, cyt. za: Kościót i państwo..., s. 81.

Św. Gelazy I, Czwarty traktat o więzach anatemy, [w:] Kościót i państwo..., s. 171.

Kościót i państwo..., s. 152. 
Funkcję zwierzchnią w Kościele pełni stosowny biskup, państwo natomiast zajmuje się zadaniami spoza instytucjonalnego zakresu działań Kościoła. Rozdział funkcjonalny zakładał podział zadań pomiędzy sferę tronu i ołtarza, w ramach którego władca dba o porządek świecki, troszczy się o pokój w państwie i właściwe życie poddanych. Kościół natomiast ma do wykonania zadanie ważniejsze. Jako wspólnota stanowi „mistyczne ciało” Jezusa Chrystusa. Jej przywódcą jest Mesjasz, a w kontekście odniesionym do immanencji - papież, „namiestnik Chrystusa”. Kościół prowadzi do zbawienia. Jego punktem odniesienia jest transcendencja.

Obie wspólnoty nie mieszają się ze sobą, ale nie są również rozdzielone, ponieważ jak tłumaczy Galezy: „, bojownik Boży nie wikła się w sprawy tego życia i odwrotnie, ten, kto uwikłany jest w sprawy świeckie, nie [...] pretenduje do rządzenia sprawami Boskimi" ${ }^{17}$.

W konsekwencji Gelazy I, powołując się na fakt odpowiedzialności papieża za duszę cesarza - sformułował pogląd o papieskiej supremacji1. Twierdził on bowiem, że cesarz jako członek Kościoła jest zależny w sprawach religijnych od sakramentalnej władzy papieża, który to niekiedy ma prawo do ingerencji w działanie władzy w sprawach wyłącznie świeckich ${ }^{19}$. Warto w tym kontekście przywołać słowa św. Gelazego I z listu do cesarza Anastazego: „Najłaskawszy Synu [...] schylasz pokornie czoło przed ludźmi odpowiedzialnymi za sprawy Boskie i od nich oczekujesz środków zapewniających Ci zbawienie"

Zarówno wcześniejsza koncepcja Ambrożego, jak i sformułowana później Gelazjańska były replikami na próby usankcjonowania omnipotencji cesarskiej potestas tak w materii doczesnej, jak i w sprawach religijnych. Przeprowadzone przez chrześcijańskich patriarchów obrony niezależności instytucji Kościoła tworzyły jednocześnie wizję władzy umiarkowanej i ograniczonej prawami boskimi, mającymi także sankcję historyczną w postaci praw tradycyjnych dla danej wspólnoty. Okazywało się nagle, że istnieją pewne działania, których władza podjąć nie może bez wkroczenia na grząski grunt herezji i potępienia w oczach ludu bożego oraz kościelnej hierarchii.

Koncepcja sformułowana przez Gelazego I była wstępem do teoretycznej budowy średniowiecznej wspólnoty chrześcijańskiej Christianitas. Myśl Gelazego „otwiera wszystkie bramy nadchodzącego średniowiecza” ${ }^{21}$. Idea dwóch mieczy przedstawia wizję chrześcijańskiego porządku jako pokojo-

Tamże.

T. Molnar, Pałac, Kościót i spoleczeństwo cywilne, s. 169.

Por. E. H. Kantorowicz, Dwa ciała króla, Warszawa 2007, s. 360.

Św. Gelazy I, Dwunasty list do cesarza Anastazego z roku 494, s. 167.

Kościót i państwo..., s. 152. 
wego współistnienia dwóch autorytetów, imperium i sacerdotium, w ramach jednego świata chrześcijańskiego. Formuła ta jest zarazem wzajemnym zobowiązaniem, jakie przyjmują obie władze. Chrześcijańskie państwo wspomaga Kościół w procesie ewangelizacji, prowadzi kult publiczny, umożliwia poddanym życie zgodne z nakazami religii. Kościół natomiast umacniać winien autorytet prawowitej władzy państwowej, nakłaniać lud boży do przestrzegania praw publicznych i posłuszeństwa władzy. Pochodzi ona bowiem, jeśli jest prawowita, z boskiego nadania ${ }^{22}$.

Wyżej przedstawiony sposób patrzenia na państwo znajduje swoją kontynuację w średniowiecznej teologii politycznej ${ }^{23}$, gdzie również próbowano znaleźć pewne modus vivendi w ramach stosunków między dwoma autorytetami. Idealna formuła zaproponowana przez papieża Gelazego I staje się dla zachodniej Christianitas pewnym wzorem, którym żyła ona przez całe milenium $^{24}$. Historia konfliktów cesarsko-papieskich wskazuje, że nie zawsze udawało się utrzymać Gelazjańską równowagę, niemniej jednak pastorał i miecz współpracowały ze sobą, będąc od siebie zależnymi, aż do nadejścia nowoczesności ${ }^{25}$.

P A W E G G E L A

Por. J. Bartyzel, Autorytet, http://metapedia.konserwatyzm.pl/wiki/Autorytet\#.22Dwa_ miecze.22, [dostęp: 8.06.2010].

o średniowiecznej recepcji doktryny dwóch mieczy zob. T. Dobrzeniecki, Teoria dwóch mieczy w programie sadu ostatecznego, s. 21-27.

Por. J. Bartyzel, „Dwa miecze”. Relacja Kościót-Państwo w tradycyjnym nauczaniu i w historii Christianitas, „Zawsze Wierni” 2003, nr 3, s. 30. 